\title{
Juno Descends: Ambiguous Sexuality and the Staging of the Tempest
}

\author{
Edmund Miller, Ph.D. \\ Senior Professor, English \\ Long Island University LIU-Post \\ Brookville NY 11548-1300 \\ United States
}

\begin{abstract}
The masque in The Tempest IV.i is not incomplete except in the sense that the celebration could go on indefinitely. The masque serves two purposes for Prospero: in the improbable reason it gives for the absence of Venus and Cupid, it dramatizes a warning about the importance of chastity before marriage, and through an ambiguous gendering of Juno signaled by the anomalous stage direction "Juno descends," it anticipates the fertility of the marriage of Miranda and Ferdinand. The possible doubling of Ariel, Stephano, and Trinculo as characters in the masque deepens the comment the play as a whole makes on the value of innocence and on the artificiality of gendering, particularly in the erotic subtext to the relationship of Stephano and Trinculo disclosed through their interaction with Caliban.
\end{abstract}

The Tempest is the best edited of the plays in the First Folio (Furness, Tempest, 271). Shakespeare's fellows seem to have given particular care to editing this play. For example, a list of characters is supplied (although misleadingly headed "The Names of the Actors"), and The Tempest is the only play in the Folio with completely satisfactory act and scene divisions. And it has unusually full stage directions. As W. W. Greg notes, "The text is a clean one .... The stage-directions are ample throughout, and in the case of spectacles elaborate" (418). John Jowett has suggested that these stage directions are the work of Ralph Crane, scrivener for the King's Men. Rather than mere promptbook guidelines for the actors, they are descriptive and evocative ("Conspicuously ornamental," according to Jowett, 114). Yet Crane worked for the company and was obviously trying to describe the play as it would have appeared in performance. While these elaborate stage directions may not be Shakespeare's own words, they clearly illuminate the playhouse practice of his day. And in several instances they inform us of stage business that we would not otherwise have understood. ${ }^{1}$

The staging of the masque in The Tempest IV.i is, however, curiously described by these full stage directions. We know that dramatic tastes in the Jacobean Age required such a masque scene, but the odd two-part structure of the masque in this play-a dialogue scene followed by an unrelated fertility dance-and the abrupt conclusion"Prospero starts suddenly and speaks; after which [the performers] heavily vanish"-have suggested to some readers that Shakespeare was almost out of his depth. However, he wrote perfectly well integrated masques for other late plays, so it might be well to seek another explanation for the interrupted melody of this one. There is, in fact, nothing in the text of the masque to indicate that it is brought to its conclusion prematurely-before, that is, it has done what it was intended to do. Whether it is over depends on what it was intended to do. And Prospero does seem to have a particular objective in view. I think this hitherto mysterious objective may be revealed by a study of the sexual dynamics of the play as reflected in the masque.

Just as the masque is about to begin, this curious passage of dialogue occurs in which Prospero addresses first Ferdinand and then Ariel:

\section{Prospero}

Look thou be true. Do not give dalliance

Too much the rein; the strongest oaths are straw

To th' fire i' th' blood. Be more abstemious,

Or else good night your vow!

\section{Ferdinand}

I warrant you, sir, 
The white cold virgin snow upon my heart

Abates the ardor of my liver.

Well.

\section{Prospero}

Now come, my Ariel; bring a corollary

Rather than want a spirit. Appear, and pertly!

No tongue! All eyes! Be Silent.

Prospero's words to Ariel at the end of this passage perhaps suggest that the main purpose of the masque is to reiterate for the betrothed bridegroom the necessity of remaining chaste until the marriage can be duly celebrated - certainly a novel theme for a wedding masque if there ever was one. Prospero's "Well" certainly indicates that, despite Ferdinand's charming and fervent protestation, Prospero maintains grave doubts about Ferdinand's ability to modulate his desires, for he immediately calls for a "corollary" that turns out to be the masque. And the importance of chastity in an engaged couple is, in fact, a point made clearly by the following story told by Iris in the earlier part of the masque to explain the absence of Venus and Cupid from the festivities at this betrothal celebration:

Here thought they to have done

Some wanton charm upon this man and maid,

Whose vows are, that no bed-right shall be paid

Till Hymen's torch be lighted. But in vain;

Mars's hot minion is returned again;

Her wasp-headed son has broke his arrows,

Swears he will shoot no more, but play with sparrows

And be a boy right out.

After this explanation, Juno arrives, and she and Ceres give their special blessings to the marriage. Ferdinand's comment on the quality of the performance and the nature of the spirits follows. And Ferdinand, a character made a better person by his love, comments on the masque in a way that suggests he is studying it carefully: "This is a most majestic vision, and / Harmonious charmingly. May I be bold / To think these spirits?" Without the advantage that the theater audience has of being able to see Ariel at all times and to hear him told to begin the staging of the masque, Ferdinand does not mistake Ariel for the goddess Ceres that that airy spirit doth present in the masque as Ariel himself later explains to have been the case but he does sense that Ariel is no mere player that struts and frets his hour upon the stage. Since Ferdinand is the primary audience for the masque, his attentiveness is an important point. Indeed, his inattention might have given Prospero a dramatic reason to interrupt the masque.

After Prospero confirms that these are indeed spirits he has "called to enact / [his] present fancies," Ferdinand exclaims (emphasizing the importance of the point with rhyme), "Let me live here forever! / So rare a wond'red father and a wise / Makes this place Paradise." In other words, he now accepts Prospero's magic as marking him out in nature as the proper lord of the island although Ferdinand is in his own proper country the king (as he believes). The reference to Paradise may also conjure up the image of a pre-Lapsarian Adam and Eve innocent of sex-as they are usually imagined (although not by Milton). Ferdinand has accepted the lesson of the masque and will allow the consummation of his marriage to await its proper term.

Prospero then tells Ferdinand that "There's something else to do. Hush and be mute, / Or else our spell is marred." This seems to suggest that-Prospero's doubts about Ferdinand's capacity for self-restraint having been dispelled-there is still one more thing to be done and but one. Iris then calls upon the nymphs and reapers to "help to celebrate / A contract of true love" in what the stage direction calls a "graceful dance." This stage direction goes on to say, "towards the end . . Prospero starts suddenly and speaks; after which, to a strange, hollow, and confused noise, they heavily vanish." This stage direction and the following comments made by Ferdinand and Miranda concerning Prospero's peculiar passion and distempered anger immediately after the masque account for the characterization sometimes given to it as interrupted. Prospero can no longer be worried about his daughter's chastity or his peculiar passion would be directed against Ferdinand, yet Ferdinand and Miranda comment as if Prospero is now scarcely aware of their presence. He seems to be interested in other things and calls himself to task for delaying action on them. Clearly the "something else to do" has just been done, and the proper moment has come for Prospero to speak and break the magic spell of silence sustaining the 
fertility rites. The fertility dance of nymphs and reapers was the one blessing still needed for the marriage of Ferdinand and Miranda. The spirits wish to continue perhaps that is why it is "heavily" that they vanish, that is to say, vanish with reluctance.

However, if they were to continue they could but provide more celebratory gestures of the same sort, and how fertile does the marriage need to be? "No more," Prospero says and, "Our revels now are ended," commenting not only on the end of Shakespeare's career, the quality of the masque, and the nature of his own magic, but also perhaps on the number of his grandchildren.

In performances of The Tempest Ferdinand and Miranda are often presented as too busy with each other during the masque to pay attention. Such a staging may suit the character established for Miranda in I.ii. But such a staging seems to be contradicted for Ferdinand by his intelligent comments on the performance. And it would be truly pointless of Prospero to stage a masque to insure the antenuptial chastity and postmarital fecundity of his daughter only to allow the significance to be lost on Ferdinand. Surely he would, if necessary, call the boy to attention just as he does Miranda in I.ii. Some such byplay with Prospero using his wand to separate the lovers may indeed be appropriate at the beginning of the masque, but Ferdinand must be paying attention during the early speech when the absence of Venus is explained or else the masque fails in its main purpose.

And there is something in the stage business for the masque that indicates a sufficiently spectacular stage effect just at this point to insure that everyone's attention is focused on the performance (with the possible exception of Miranda, who has lived with magic long enough to have become jaded about it but who is in the throes of first love and perhaps unable to concentrate on anything outside this brave new world of experience). Fifteen lines before Iris tells the story of Venus's absence and just before the entrance of Ceres, whose approach is noted by Iris and who speaks immediately, there is a tantalizing stage direction in the First Folio: "Juno descends." Since Juno is acknowledged by the other characters in the masque only after Iris's remarks about Venus, the stage direction has been variously explained. The direction may be misplaced; it may be a prompt cue not meant to take immediate effect, or it may indicate that the wheels of the deus ex machina worked with peculiar slowness at the reconstructed Globe.

This last explanation, perhaps the least satisfactory on the face of it, may provide the germ of an idea illuminating what is happening in the masque by design. A conspicuously slow descent of Juno would direct attention to the masque. The audience - the one on stage as well as the one in the pit — would strain to hear what Iris is saying as a way of seeking to understand the laborious descent. That Iris provides no such explanation is beside the point; her information still becomes part of the record.

The arrival of Juno immediately after Iris's speech presents its own difficulties. If she has indeed been descending in a machine, the phrasing of the words with which Ceres heralds her appearance on stage seems at first sight to be peculiarly inapt: "Highest queen of state, / Great Juno, comes; I know her by her gait." A goddess who descends in a machine can have had little opportunity to illustrate her majestic gait. But perhaps this is the point. The serious heroic masque of chastity having been completed, the comic antemasque of fertility can begin.

And the comedy may easily have been more than a simple blunder in Ceres's phrasing. Less subtly, Juno may stumble as she alights. Indeed, the usual meaning of the adjective Junoesque and the use here of "bounteous" in Juno's first lines suggest other even more broadly comic possibilities. If the part of Juno were meant to be taken by a man and not by one of the boy apprentices, this would change Ceres's comment "I know her by her gait" from a careless lapse into a calculated joke about clumsiness. The comedian would then inevitably adjust his bosom when sorting himself out after alighting gracelessly from the celestial basket. He would be doing so while reading his first lines "How does my bounteous sister? Go with me to bless this twain . . .." By thus calling attention to his Junoesque breasts while making these observations, he would turn them into big laugh lines, inaugurating a change of mood appropriate for the second half of the masque. After the house has settled, Juno sings her blessings, which would have a special symbolic magic if recited by a figure so conspicuous in its ambiguous gendering.

We might even speculate about which of the actors doubled in this part. It would most reasonably be one of the comedians in the company, specifically someone in the Caliban/Stephano/Trinculo (group off stage at this time), and since the part requires singing, it might most naturally go to the actor playing the burly Stephano. 
The actor who could make a good Stephano would make a very strange woman, but this is precisely the point. Since this actor must wear elaborate makeup as Juno he might not even be recognized incongruously participating in the masque while Stephano is supposedly plotting against Prospero. And if he were recognized, the audience would simply pretend not to notice as it would were one of the actors who played a sailor to be recognized doubling as one of the courtier or sprites. And such a casting of the Stephano actor as Juno would have the additional advantage of allowing the play to be performed with fewer apprentices skilled enough to read parts with substantial numbers of lines, for if Shakespeare had a large number of boys available at this time, it is at least curious that he wrote only one proper female role in this play.

In addition to Miranda, Ariel and the sprites are, of course, meant to be played by boys, but Trinculo might have been played by a boy or by a very young adult actor just out of his apprenticeship. In fact, in a particularly tight casting situation the actor playing Trinculo could have doubled as Iris. The casting of a boy actor who would normally play a woman as a character like Trinculo would automatically give an androgynous cast to the character, for as Frank Lentricchia has recently pointed out all ascriptions of gender are problematical in their essence and culturally determined (see also Garber and Rackin). Ariel himself is a sexually ambiguous character for the same reason, a point some productions have taken advantage of by casting a woman in the part in this otherwise almost womanless play. But the point of such casting in the modern theater is often less to make a cultural statement than to provide work for actresses.

Whether or not it was Shakespeare's intention to have Trinculo played by a boy, the character of Trinculo presents a number of interpretive difficulties that are resolved if he is imagined as a young man only just out of his teens if not younger. When Trinculo first appears Caliban attempts to hide from him by the improbable device of lying down in the middle of the stage and covering himself with his cloak (II.ii). Like Miranda, who has never seen a real man, Caliban has never seen a half-grown man. Yet just before Trinculo enters, Caliban says he is afraid he will be punished for dereliction of duty by spirits who will "Fright [him] with urchin shows." Trinculo may be just such an urchin show. He is certainly silly and naïve-and in a very different way than Caliban is.

The way he becomes acquainted with Caliban is quite as improbable as the way that creature chooses to hide himself, and Trinculo does not yet have Stephano's excuse of drunkenness for his curious behavior. Having espied the exotic heap in the middle of the stage, Trinculo says, "What have we here? a man or a fish? dead or alive? a fish! He smells like a fish; a very ancient and fishlike smell; a kind of not the newest Poor John. A strange fish." Yet when a closer examination proves that the creature is "Legged like a man. And his fins like arms!" Trinculo, perhaps frightened by thunder, determines "to creep under his gaberdine," commenting philosophically that "Misery acquaints a man with strange bedfellows."

However, even the thunder is an interpolation of modern editors. Trinculo merely observes, "Alas, the storm is come again! My best way is too creep under his gaberdine." In fact, so far as the stage directions of the First Folio provide a guide, it might as easily be not thunder but a conventional gesture of testing for rain by holding out the palm of his hand by which Trinculo contrives to convince himself that there is a pressing reason for him to adopt the eccentric expedient of creeping under the gaberdine.

The explanation why he might want to do so is not far to seek. Stephano's description of Caliban and Trinculo under the blanket of Caliban's cloak tells the whole story. "This," he says, "is some monster of the isle, with four legs, who has got, as I take it, an ague." The reference to four legs is repeated enough times to make it clear that the appropriate stage direction here is "Under the gaberdine, Trinculo and Caliban make the beast with two backs"-or "four legs." In fact, Trinculo is carrying on with sufficient enthusiasm to cause Caliban to cry out several times, "Do not torment me! O," or the like. Caliban is unfamiliar with the sort of thing happening to him, yet he has a line that would suggest (to the audience) that he is getting aroused: "I'll bring my wood home faster." Although Caliban in his natural savagery may have attempted to rape Miranda, in his mooncalf innocence he has no experience of a decadent simpleton like Trinculo, a silly and naïve innocent from the real world but a fugitive from a real world that always corrupts the innocent (as the bookish Prospero too late discovered) and a real world in which it is only too likely that a boy on shipboard would have had sexual experiences with sailors. Indeed, when Stephano is about to discover the heap of Caliban and Trinculo, he enters singing a bawdy sea chantey, the moral of which is that, when a woman has a "tongue with a twang," why "Then to the sea, boys, and let her go hang!" That is, men at sea can get along very nicely without women. 
In addition, Trinculo is called a "jester" in the list of the names of the characters attached to the first appearance of this play in the First Folio by Shakespeare's fellows. The mattachine tradition associates with the campy manner appropriate to a court jester an expectation of alternative sexuality. Caliban, who must be speaking literally since he can know nothing of the garb of jesters, calls Trinculo a "pied ninny" and a "scurvy patch" (III.ii), suggesting that Trinculo wears the formal party-colored costume of a court jester.

Support for this reading of Trinculo's psychosexual and employment history is provided by Stephano's proprietary attitude toward Trinculo; he several times calls Trinculo "boy." And shortly after Stephano draws Trinculo forth from under the blanketing "by the lesser legs" ("If any be Trinculo's legs, these are they"), Stephano makes the sly joke at his fellow's expense: "Though thou canst swim like a duck, thou art made like a goose."

And as Stephano is actually in the act of pulling Trinculo out he asks, "How cam'st thou to be the siege of this mooncalf? Can he vent Trinculos?" Trinculo has been laying siege to Caliban in the sense of tormenting him, but the word also carries an erotic suggestion. Indeed the primary meaning of siege here is probably "excrement" (from siege in the sense "seat," as in "Siege Perilous"); the primary meaning of vent is certainly "make wind." Stephano seems to be willing to assume the worst about where Trinculo has been, and the very fact that he does not make more fun of Trinculo on this score may indicate that it is not a point that needs belaboring: he would naturally expect to find Trinculo making the beast with four legs under a blanket in the company of some wild islander with a fishlike smell.

The objection ${ }^{3}$ that might be made to this reading is that Trinculo calls Caliban a "perfidious and drunken monster" and takes every opportunity to belittle him: "I shall laugh myself to death at this puppy-headed monster. A most scurvy monster. I could find it in my heart to beat him-" (II.ii). But Trinculo clearly protests too much (and whatever he had been doing under the cloak has already tormented Caliban). He is trying to deny that in his world, "There would this monster make a man; any strange beast there makes a man," as he explains just before joining Caliban under his cloak. And some boys like a fish-like smell when a "strange beast there makes a man." Trinculo certainly would have become used to such a smell among sailors. Caliban's expressed dislike for Trinculo, on the other hand, seems more genuine. His cry from under the cloak "Do not torment me, prithee; I'll bring my wood home faster," as noted earlier, has an obscene subtext, but the primary meaning is simply that he does not understand - or like - what is going on. His mooncalf innocence protects him at least so much. And, of course, whether or not Trinculo is sexually harassing Caliban, the audience can hardly avoid finding a bawdy dimension to this episode: any physical contact between males is threatening to adolescent self-awareness and thus a staple of adolescent humor-at least when others fall into such contact.

\section{Notes}

${ }^{1}$ Mowat uses narrative interruptions in The Tempest to illustrate the suggestion of simultaneous action that she sees as one of Shakespeare's primary goals in the romances. The use of stage directions in this play even more clearly suggests a pattern of narrative simultaneity. Mooney discusses the general issue of how actors' stage locations affect audience perception of a Shakespearean scene.

${ }^{2}$ The usual reading given to "corollary" in this passage is "surplus," so one meaning of Prospero's words is a request that Ariel provide more than enough spirits for the masque rather than run the risk of trying to put it on with too few. I read "corollary" in the mathematical sense of an implicit consequence. But in either case Prospero calls for the masque as a response to his dubiousity about Ferdinand's ability to control the ardor of his liver.

${ }^{3}$ Another objection that might be raised to this reading is Shakespeare's conspicuous avoidance of allusions to male/male eroticism in Richard II, a play in which they might have helped explain character motivation. Does he perhaps avoid the subject on principle? The problem cannot be Elizabethan censorship since Marlowe fills plays on similar subjects with explicit indications of the male-focused sexuality of the English king Edward II and the French king Henry III. The "Lipsbury pinfold" reference in King Lear suggests that Shakespeare could make a joke about male/male sexuality when the occasion was appropriate, and the Sonnets certainly make no effort to avoid the possibility of an erotic interpretation of the friendship of two men (for a full consideration of the homoeroticism of the Sonnets, see Pequigney although his reading is completely superseded now by the elegant simplicity of Millán's reading of paternal concern). Indeed a similar erotic note appears in Two Noble Kinsmen, written shortly after The Tempest in collaboration with a writer who seems to have been exclusively homosexual in his personal life. The explanation for the omission of the subject in Richard II is perhaps the simple one that Shakespeare did not recognize eroticism as the cause of Richard's dependence on his male favorites because his historical research for all of his history plays was extremely casual. 
In the same play he gives no indication that he is familiar with the fact that Richard's queen would have been a mere child at the time of the action or that the Duchess of York was, on the one hand, the daughter of Richard's half-sister and thus his niece by blood as well as his aunt by marriage but, on the other hand, only the step-mother of the Duke of Aumale for whom he has her plead so eloquently (Miller).

Orgel ("Nobody's Perfect") implausibly assumes that Shakespeare was familiar with the erotic nature of King Richard's infatuations, suggesting that the elimination of sex from the play makes it more political-and made it more politically dangerous in its own day (see also Porter). On Caliban as monster see Vaughan and Vaughan.

\section{Works Cited}

Furness, Horace Howard, ed. The Tempest. New York: Dover, 1964.

Garber, Marjorie. Vested Interests: Cross-Dressing and Cultural Anxiety. New York: Routledge, 1991.

Greenaway, Peter, director. "Prospero's Books," motion picture. Starring [Sir] John Gielgud as Prospero with Michael Clark as Caliban. Released by Miramax Films 1991.

Greg, [Sir] W[alter] W[ilson]. The Shakespeare First Folio: Its Bibliographical and Textual History. Oxford: Clarendon, 1955.

Jowett, John. "The New Created Creatures: Ralph Crane and the Stage Directions in The Tempest." Shakespeare Survey 36 (1983): 107-20.

Lentricchia, Frank. Ariel and the Police: Michel Foucault, William James, Wallace Stevens. Madison: U of Wisconsin P, 1988.

Millán, Juan Daniel. "Master William's Hamnet: A New Theory on Shakespeare's Sonnets." http://williamshakespearessonnets.blogspot.com/2016/04/master-williams-hamnet-new-theory-on.html. Accessed Wednesday, April 20, 2016

Miller, Edmund. Review of Shakespeare's English Kings by Peter Saccio. The Augustan 19 (1978): 12122.

Mooney, Michael. Shakespeare's Dramatic Transactions. Durham: Duke U P, 1990.

Mowat, Barbara A. The Dramaturgy of Shakespeare's Romances. Athens: U of Georgia P, 1976.

Orgel, Stephen. "Nobody's Perfect; or Why Did the English Stage Take Boys for Women?" South Atlantic Quarterly 88 (1989): 7-29.

Pequigney, Joseph. Such Is My Love: A Study of Shakespeare's Sonnets. Chicago: U of Chicago P, 1985.

Peterson, Douglas L. Time, Tide, and Tempest: A Study of Shakespeare's Romances. San Marino: Huntington Library, 1973.

Porter, Joseph A. "Marlowe, Shakespeare, and the Canonization of Heterosexuality." South AtlanticQuarterly 88 (1989): 127-48.

Rackin, Phyllis. "Androgyny, Mimesis, and the Marriage of the Boy Heroine on the English Renaissance Stage." PMLA 102 (1987): 29-41.

Shakespeare's Tragedies. New York: Frederick Ungar, 1978.

Shakespeare, William. The Tempest. Ed. Robert Langbaum. New York: New American Library, 1964.

Vaughan, Alden T., and Virginia Mason Vaughan. Shakespeare's Caliban: A Cultural History. New York: Cambridge U P, 1991. 